\title{
MODEL PENGEMBANGAN KURIKULUM PAI SMP DI KOTA SEMARANG
}

\author{
Toha Makhshun ${ }^{1}$
}

\begin{abstract}
A research based article "The model of PAI curriculum development at Junior high school in Semarang" is intended to see how far the development of PAI curriculum at Junior High School in Semarang. The main problem in this research is: how is the development of PAI curriculum at Junior high school in Semarang.

The techniques of collecting data applied in this research are (1) observation to collect data of PAI curriculum development application at NASIMA Junior High School and Sultan Agung Islamic Junior High School I; (2) An interview to get a clear, comprehensive and indepth information about PAI curriculum policy and it's implementation at Nasima and Sultan Agung Islamic Junior High School I; (3) documentation, is for collecting a history documentation, to formulate a curriculum. Descriptive-interpretative is used to analyze collected data.

The reseach result shows that Nasima Junior High School and Sultan Agung Junior High School - Semarang have innovative and strategic steps in developing a curriculum. The curriculum is interpretated based on the needs of school and society through a religion and Islamic school culture activity.
\end{abstract}

\section{ABSTRAK}

Artikel dengan judul "Model Pengembangan Kurikulum PAI SMP di kota Semarang" dimaksudkan untuk melihat sejauhmana pengembangan kurikulum PAI SMP di kota Semarang. Permasalahan utama dalam penelitian ini Bagaimana Pengembangan kurikulum PAI pada tingkat SMP di kota Semarang.

Teknik Penumpulan data yang digunakan dalam penelitian ini ada tiga, yaitu: (1) observasi untuk memperoleh data tentang pelaksanaan pengembangan kurikulum PAI di SMP Nasima dan SMP Islam Sultan agung 1 ; (2) wawancara untuk mendapatkan informasi-informasi yang lebih jelas, lengkap dan sedalam-dalamnya tentang kebijakan kurikulum PAI dan implementasi kebijakan pekurikulum PAI di SMP Nasima dan SMP Islam Sultan Agung 1; (3) dokumentasi, untuk memperoleh dokumen historis perumusan kurikulum. Analisis data yang digunakan adalah deskriptif interpretatif.

Hasil penelitian menunjukkan bahwa, SMP Nasima Semarang dan SMP Islam Sultan Agung 1 Semarang memiliki langkah dan strategi yag inovatif

Dosen Program Studi Pendidikan Agama Islam (PAI) Jurusan Tarbiyah Fakultas Agama Islam (FAI) Universitas Islam Sultan Agung (UNISSULA) Semarang 
dalam mengembangkan sebuah kurikulum, kurikulum benar benar ditafsirkan sesuai dengan kebutuhan seklah dan masyarakat yaitu melalui kegiatan yang disebut kegiatan keagamaan dan Budaya Sekolah Islami.

\section{A. Pendahuluan}

Pendidikan memiliki peran penting dalam kehidupan manusia. Usaha-usaha pendidikan bagi manusia menjadi suatu kebutuhan pokok guna menunjang dan meningkatkan potensi yang dimiliki manusia. Potensi tersebut dalam istilah agama Islam sering disebut fitrah (Drs.H.Baharuddin, 2011, hal. 20) sebagaimana dalam al-Quran surat al-Rum(30) ayat 30 : Artinya : Maka hadapkanlah wajahmu dengan lurus kepada agama Allah; (tetaplah atas) fitrah Allah yang Telah menciptakan manusia menurut fitrah itu. tidak ada peubahan pada fitrah Allah. (Itulah) agama yang lurus; tetapi kebanyakan manusia tidak mengetahui (al-Rum(30) ayat 30) (Al-Quran dan Terjemahnya, 2005, hal. 407)

Muhammad bin Asyur sebagaimana di kutip oleh Quraish Shihab, menafsirkan kata fitrah pada ayat di atas sebagai bentuk dan sistem yang diwujudkan Allah pada setiap makhluk, fitrah yang berkaitan dengan manusia adalah apa yang diciptakan Allah pada manusia yang berkaitan dengan jasmani dan akalnya (serta ruhnya) (Shihab, 2006, hal. 285)

Menurut Achmadi kata fitrah berasal dari kata fathara yang sepadan dengan khalaqa dan ansyaa, biasanya kata tersebut dalam Al-Quran digunakan untuk menunjukkan pengertian mencipta sesuatu yang sebelumnya belum ada dan masih merupakan pola dasar yang perlu penyempurnaan, kata-kata yang biasanya digunakan untuk menunjukkan bahwa Allah menyempurnakan pola dasar tersebut adalah kata ja'ala yang artinya menjadikan. Perwujukan dan penyempurnaan selanjutnya diserahkan kepada manusia (Achmadi, 2010, hal. 43)

Manusia membutuhkan pendidikan untuk menjalani kehidupannya. Pendidikan memberi bekal manusia untuk menjalani kehidupan menjadikan dewasa dengan dapat menentukan hal yang baik dan benar, dan menjalani tugas untuk belajar sepanjang hayat, dalam istilah Ghazaly menjadi insan purna yang selalu mendekatkan diri kepada Allah dan mendapatkan kebahagiaan hidup di dunia dan akhirat (Sulaiman, 1993, hal. 24).

Era reformasi telah membawa perubahan-perubahan mendasar dalam berbagai kehidupan termasuk kehidupan pendidikan. Salah satu perubahan mendasar adalah manajemen Negara, yaitu dari manajemen berbasis pusat menjadi manajemen berbasis daerah. Secara resmi, perubahan manajemen ini telah diwujudkan dalam bentuk Undang-Undang Republik Indonesia No. 22 Tahun 1999, yang kemudian direvisi dan disempurnakan menjadi Undang-Undang No.32 tahun 2004 tentang Pemerintahan Daerah. 
Pedoman pelaksanaannyapun telah dibuat melalui Peraturan Pemerintah Republik Indonesia No. 25 tahun 2000 tentang Kewenangan Pemerintah dan Kewenangan Propinsi sebagai Daerah Otonom.

Konsekuensi logis dari Undang-Undang dan Peraturan Pemerintah tersebut dalam bentuk perubahan arah paradigma pendidikan, dari paradigma lama ke paradigma baru, yang tentu juga berdampak pada proses formulasi kebijakan pendidikan Islam. Secara ideal, paradigma baru pendidikan tersebut mestinya mewarnai kebijakan pendidikan baik kebijakan pendidikan yang bersifat substantif maupun implementatif.

Lahirnya undang-undang SISDIKNAS No 20 tahun 2003, telah memberikan arah baru dalam dunia pendidikan, khususnya dunia pendidikan Islam baik bagi lembaga pendidikan Islam maupun materi pendidikan agama Islam. Kenyataan tersebut, menunjukkan bahwa pendidikan agama mempunyai kedudukan dan peranan penting dalam pembangunan negara dan masyarakat Indonesia.

Dalam PP No 19 Tahun 2005 tentang Standar Nasional Pendidikan pasal 6, pasal 7 di sebutkan bahwa kerangka dasar dan struktur kurikulum wajib memuat kelompok mata pelajaran agama, (Grafika, 2005)

Keluarnya Peraturan Pemerintah (PP) Nomor 55 tahun 2007 tentang pendidikan agama dan pendidikan keagamaan, diharapkan dapat membawa perubahan pada sisi menagerial dan proses pendidikan Islam. Dalam PP No. 55 tahun 2007 pasal 5 ayat 8 disebutkan "Satuan pendidikan dapat menambah muatan pendidikan agama sesuai kebutuhan". Pada ayat berikutnya disebutkan "Muatan sebagaimana dimaksud pada ayat (8) dapat berupa tambahan materi, jam pelajaran, dan kedalaman materi”.

Dari pasal tersebut ada dua hal yang terkait dengan kebijakan Pendidikan Agama Islam, yaitu: 1). Dari sisi kelembagaan bahwa lembaga pendidikan Islam diberi wewenang untuk mengembangkan dan mengelola lembaganya sesuai dengan visi dan misi lembaga, 2). Dari sisi materi yang diberikan kepada anak didikpun dapat di berikan sesuai dengan kebutuhan, baik ditambah secara materi, maupun pendalaman materi.

Hal tersebut tentu sejalan dengan tujuan pendidikan agama Islam, dimana pendidikan agama Islam adalah upaya sadar dan terencana dalam menyiapkan peserta didik untuk mengenal, memahami, menghayati, hingga mengimani, bertakwa dan berakhlak mulia dalam mengamalkan ajaran Islam dari sumber utamanya kitab suci Al-qur'an dan Hadits melalui kegiatan bimbingan, pengajaran, latihan serta penggunaan pengalaman (Depdiknas, 2003, hal. 7), sehingga Pendidikan Agama Islam bertujuan untuk memberikan nilai spiritual keagamaan. Hal ini mengandung arti, agama bukan hanya diajarkan (disampaikan dalam bentuk rumusan-rumusan konsep atau teori) namun harus dididikkan. Artinya, dirumuskan dalam perbuatan-perbuatan 
nyata yang terakumulasi dalam sebuah kepribadian yang utuh (menyangkut aspek kognitif, afektif, dan aspek psikomotorik) sehingga pendidikan agama Islam akan menghasilkan manusia-manusia yang memiliki pengetahuan, sikap, dan perilaku yang mencerminkan nilai-nilai Islam.

Undang-undang dan peraturan telah disusun sedemikian sempurna, bahkan secara historis semakin lama pendidikan agama Islam memiliki ruang yang luas dan terbuka guna mewujudkan tujuan yang ideal, namun hingga saat ini apa yang dicita-citakan dan apa yang diamanatkan oleh undang-undang tersebut untuk menghasilkan manusia-manusia yang memiliki pengetahuan, sikap, dan perilaku yang mencerminkan nilai-nilai Islam. Agar peserta didik secara aktif mengembangkan potensi dirinya untuk memiliki kekuatan spiritual keagamaan, pengendalian diri, kepribadian, kecerdasan, akhlak mulia, serta keterampilan yang diperlukan dirinya, masyarakat, bangsa, dan negara belum terwujud.

\section{B. Kurikulum Pendidikan Agama Islam \\ 1. Pendidikan Agama Islam}

Burhanudin Salam yang mengutip Langeveld mengemukakan bahwa pendidikan adalah bimbingan kepada orang yang belum dewasa untuk mencapai kedewasaan" (Salam, 2002, hal. 3-4.).

Ahmad D. Marimba menyatakan bahwa pendidikan adalah suatu proses bimbingan terbentuknya kepribadian yang utama (Marimba, Pengantar Filsafat Pendidikan Islam, 1971, hal. 2).

Anshari mendefinisikan pendidikan sebagai proses bimbingan kepada peserta didik dalam mengembangkan potensi peserta didik dalam kurun waktu tertentu, menggunakan metede tertentu kepada suatu tujuan (H. Endang Syaifuddin Anshari, 2004, hal. 149).

Sehingga pendidikan adalah usaha yang secara sadar dilakukan untuk melakukan bimbingan dan arahan dengan menggunakan suatu bahan, matode, alat, menuju terbentuknya kepribadian yang sempurna

Pendidikan Agama Islam adalah "upaya mendidikkan agama Islam, atau ajaran Islam dan nilai-nilainya agar menjadi pandangan dan sikap hidup, wujudnya yaitu pelajaran agama Islam yang diselenggarakan di lembagalembaga pendidikan umum sebagai suatu mata pelajaran" (Muhaimin, Paradigma Pendidikan Islam, 2012, hal. 104).

Abdul Majid mendefinisikan pendidikan agama Islam sebagai usaha mempersiapkan peserta didik untuk meyakini, memahami, dan mengamalkan ajaran Islam melalui kegiatan bimbingan, pengajaran atau pelatihan (Abdul Majid, Belajar dan Pembelajaran, 2012, hal. 13).

Achmadi mendefinisikan pendidikan agama Islam sebagai usaha yang ditekankan untuk mengembangkan fitrah keberagamaan (religiousitas) 
subjek didik agar lebih mampu memahami, menghayati dan mengamalkan ajaran Islam (DR.Achmadi, 2010, hal. 32)

Ansyari mendefinisikan pendidikan agama Islam sebagai proses bimbingan oleh subjek didik terhadap perkembangan jiwa dan raga objek didik yang materi didiknya adalah akidah Islam, syari'ah (ibadah dan muamalah), dan akhlak (H. Endang Syaifuddin Anshari, 2004, hal. 150)

Dalam kurikulum 2004 tentang standar kompetensi mata pelajaran Pendidikan Agama Islam, memberikan definisi secara rinci, yaitu: Pendidikan Agama Islam adalah upaya sadar dan terencana dalam menyiapkan peserta didik untuk mengenal, memahami, menghayati hingga mengimani, bertakwa, dan berakhlak mulia dalam mengamalkan ajaran agama Islam dari sumber utamanya kitab suci Al-Quran dan Hadits, melalui kegiatan bimbingan, pengajaran, latihan, serta penggunaan pengalaman. Dibarengi tuntunan untuk menghormati penganut agama lain dalam hubungannya dengan kerukunan antar umat beragama dalam masyarakat hingga terwujud kesatuan dan persatuan bangsa (Depdiknas, 2003, hal. 7).

Sehingga dapat disimpulkan Pendidikan Agama Islam adalah upaya sadar yang dilakukan untuk mendidikkan ajaran Islam dan nilai-nilai Islam yang wujudnya adalah berupa bidang studi agama Islam oleh pendidik terhadap peserta didik melalui proses bimbingan. Pendidikan Agama Islam merupakan bagian atau sub sistem dari Pendidikan Islam.

\section{Kurikulum}

Ketika membicarakan kurikulum ada beberapa pengertian yang berbeda, tergantung dari sudut pandang masing-masing dalam melihat.

Istilah kurikulum berasal dari bahasa latin "a running course dan terdapat pula dalam bahasa Prancis to run yaitu berlari, kemudian istilah ini digunakan untuk sejumlah courses atau mata pelajaran yang harus ditempuh untuk mencapai suatu gelar atau ijazah" (Nasution, 1993, hal. 9).

Dalam pandangan lama kurikulum diartikan "sebagai sejumlah mata pelajaran yang harus ditempuh oleh murid untuk memperoleh ijazah" (Hamalik, Pengembangan Kurikulum Dasar-Dasar dan Perkembangannya, 1990, hal. 4).

Dari pengertian di atas dapat dipahami bahwa: Kurikulum terdiri dari mata pelajaran, Mata pelajaran tersebut berisi sejumlah informasi atau pengetahuan, Tujuan untuk mempelajarinya untuk memperoleh gelar atau ijazah.

Dalam perkembangannya, penekanan arti kurikulum terletak pada pengalaman belajar, dengan titik tekan tersebut kurikulum diartikan "sebagai segala pengalaman yang disajikan kepada para siswa di bawah pengawasan dan pengarahan sekolah" (Aly, 1999, hal. 162). 
Romine (1954) sebagaimana dikutip Hamalik merumuskan pengertian kurikulum sebagai berikut : "Curriculum is interpreted to mean all of the organized courses, activities, anf experiences which pupils have under direction of the school, whether in the classroom or not" (Hamalik, Administrasi dan Supervisi Pengembangan Kurikulum, 1992, hal. 4).

Nata mendefinisikan kurikulum dengan segala hal yang diberikan sekolah kepada anak didik baik di dalam sekolah maupun di luar sekolah dengan maksud untuk menolong dan mengembangkan seluruh segi dan tingkah laku anak didik sesuai dengan tujuan pendidikan (Nata, 2012, hal. 124-125)

Ella mengutip pendapat Cronbleth mendefinisikan kurikulum "sebagai kegiatan sosial yang berkesinambungan yang dipertajam oleh berbagai pengaruh kontekstual di dalam dan di luar kelas, serta diwujudkan secara interaktif terutama oleh guru dan peserta didik" (Yulaelawati, 2004, hal. 25).

Dalam Undang-Undang Republik Indonesia No. 20 Tahun 2003 pasal 1 ayat 19 disebutkan: "Kurikulum adalah seperangkat rencana dan pengaturan mengenai tujuan, isi, dan bahan pelajaran serta cara yang digunakan sebagai pedoman penyelenggaraan kegiatan pembelajaran untuk mencapai tujuan pendidikan tertentu" (Depdiknas, 2003, hal. 4).

Dari pengertian tersebut kalau dijabarkan paling tidak ada empat komponen kurikulum, yaitu: tujuan, isi, bahan pelajaran (materi), kegiatan pembelajaran dan evaluasi/penilaian. Keempat komponen tersebut merupakan satu kesatuan yang masing-masing harus memiliki kesesuaian atau relevansi, baik kesesuaian antara kurikulum dengan tuntutan, kebutuhan, kondisi dan perkembangan masyarakat, atau kesesuaian antara komponen-komponen kurikulum, yaitu isi sesuai dengan tujuan, proses sesuai dengan isi dan tujuan, demikian juga evaluasi/penilaian sesuai dengan proses, isi dan tujuan (Sukmadinata, 1997, hal. 102).

Dari pengertian tersebut kalau dijabarkan paling tidak ada empat komponen kurikulum, yaitu: tujuan, isi, bahan pelajaran (materi), kegiatan pembelajaran dan evaluasi/penilaian. Keempat komponen tersebut merupakan satu kesatuan yang masing-masing harus memiliki kesesuaian atau relevansi, baik kesesuaian antara kurikulum dengan tuntutan, kebutuhan, kondisi dan perkembangan masyarakat, atau kesesuaian antara komponen-komponen kurikulum, yaitu isi sesuai dengan tujuan, proses sesuai dengan isi dan tujuan, demikian juga evaluasi/penilaian sesuai dengan proses, isi dan tujuan (Sukmadinata, 1997, hal. 102).

Sehingga dapat disimpulkan kurikulum adalah seperangkat kegiatan yang direncanakan dan dirancangkan oleh seorang pendidik kepada peserta didik dalam kegiatan pembelajaran untuk mencapai tujuan pendidikan. 
Dari pengertian tersebut, kurikulum memiliki tafsiran yang lebih luas, tidak terbatas pada mata pelajaran saja tetapi meliputi seluruh pengalaman yang diberikan kepada peserta didik.

Dengan pengertian yang baru tersebut tidak ada pemisahan antara kurikulum formal (intrakurikuler) dan non formal (kokurikuler dan ekstrakurikuler), karena kegiatan-kegiatan di luar kelas (non formal) sudah tercakup dalam pengertian kurikulum sehingga pelaksanaan kurikulum tidak hanya di dalam kelas, tetapi juga di luar kelas, sesuai dengan tujuan yang hendak dicapai.

\section{a. Peranan dan Fungsi Kurikulum}

Kurikulum sebagai program pendidikan yang telah direncanakan memiliki peranan yang penting bagi pendidikan. Hamalik mengungkapkan paling tidak ada tiga peranan kurikulum yang penting, yaitu :1) Peranan konservatif, yaitu mentransmisikan dan menafsirkan warisan sosial kepada generasi muda, 2) Peranan kritis atau evaluatif, yaitu menilai, memilih unsurunsur kebudayaan yang akan diwariskan. 3) Peranan kreatif, yaitu mencipta dan menyusun sesuatu yang baru sesuai dengan kebutuhan masa sekarang dan masa yang akan datang dalam masyarakat. (Hamalik, Pengembangan Kurikulum Dasar-Dasar dan Perkembangannya, 1990, hal. 8-10).

Dari uraian di atas, peranan penting yang diemban kurikulum yaitu kurikulum yang disusun dalam sebuah lembaga pendidikan harus mampu untuk mengartikan nilai-nilai luhur yang ada dalam masyarakat agar nilainilai luhur tersebut tidak akan musnah terbawa perubahan waktu, sekaligus melakukan seleksi terhadap kebudayaan asing yang masuk sehingga nilainilai luhur yang dimiliki akan tetap terjaga. Agar nilai-nilai luhur tesebut mudah diterima oleh anak didik maka kurikulum harus kreatif, tidak monoton.

Di samping kurikulum memiliki peranan, kurikulum juga memiliki atau mengemban berbagai fungsi. Hamalik mengutip pendapat Alexander Inglis menyatakan bahwa kurikulum memiliki fungsi : 1) Fungsi penyesuaian, 2) Fungsi pengintegrasian, 3) Fungsi deferensiasi, 4) Fungsi persiapan,5) Fungsi pemilihan, 6)Fungsi diagnostik (Hamalik, Pengembangan Kurikulum Dasar-Dasar dan Perkembangannya, 1990, hal. 10-11).

Dalam kehidupan yang serba cepat berkat perkembangan ilmu dan teknologi sehingga kurikulum harus mampu menjalankan fungsinya dengan baik yaitu harus mampu membantu peserta didik untuk adaptasi dan menyesuaikan dirinya dengan lingkungan, mengingat peserta didik adalah bagian integral dari masyarakat sehingga selain membantu peserta didik menyesuaian dirinya dengan lingkungan kurikulum juga memiliki fungsi pengintegrasian. 
Kehidupan masyarakat yang memiliki latar belakang sosial yang berbeda, kurikulum harus mampu memberikan layanan terhadap perbedaanperbedaan tersebut dengan melakukan diagnosa dan memberikan beberapa alternatif pilihan kepada peserta didik sehingga peserta didik siap dalam menghadapi kehidupan.

\section{b. Kegiatan Kurikulum}

Pada bagian terdahulu telah disebutkan bahwa "kurikulum adalah segala pengalaman yang disajikan kepada para peserta didik di bawah pengawasan dan pengarahan sekolah" (Aly, 1999, hal. 162).

Dalam Undang-Undang Republik Indonesia No. 20 Tahun 2003 pasal 1 ayat 19 disebutkan: "Kurikulum adalah seperangkat rencana dan pengaturan mengenai tujuan, isi, dan bahan pelajaran serta cara yang digunakan sebagai pedoman penyelenggaraan kegiatan pembelajaran untuk mencapai tujuan pendidikan tertentu" (Depdiknas, 2003, hal. 4).

Sehingga dapat disimpulkan kurikulum adalah seperangkat kegiatan yang direncanakan dan dirancangkan oleh seorang pendidik kepada peserta didik dalam kegiatan pembelajaran untuk mencapai tujuan pendidikan.

Dari pengertian tersebut, kurikulum memiliki tafsiran yang lebih luas, tidak terbatas pada mata pelajaran saja tetapi meliputi seluruh pengalaman yang diberikan kepada peserta didik.

Dengan pengertian yang baru tersebut tidak ada pemisahan antara kurikulum formal (intrakurikuler) dan nonformal (kokurikuler dan ekstrakurikuler), karena kegiatan-kegiatan di luar kelas (nonformal) sudah tercakup dalam pengertian kurikulum sehingga pelaksanaan kurikulum tidak hanya di dalam kelas, tetapi juga di luar kelas, sesuai dengan tujuan yang hendak dicapai.

Dari konsep ini, kurikulum yang lengkap terdiri dari kegiatan intrakurikuler, kokurikuler, dan ekstrakurikuler.

\section{1) Kegiatan Intrakurikuler}

Kegiatan intrakurikuler adalah "kegiatan yang dilakukan di sekolah yang penjatahan waktunya telah ditetapkan dalam struktur progam dan dimaksudkan untuk mencapai tujuan minimal (kompetensi dasar) dalam masing-masing mata pelajaran" (Setiawati, 1993, hal. 15).

Pada dasarnya "kegiatan intrakurikuler adalah kegiatan kurikuler pada waktu kegiatan belajar-mengajar berlangsung di sekolah atau di lingkungan sekolah berdasarkan struktur progam yang telah ditetapkan" (Setiawati, 1993, hal. 15), sehingga "dalam pelaksanaannya harus sesuai dengan waktu yang telah ditetapkan dalam jadwal, harus mengacu pada tujuan instruksional 
khusus (indikator hasil belajar), mengusahakan agar bahan yang diajarkan dipahami peserta didik" (Setiawati, 1993, hal. 16).

2) Kegiatan Kokurikuler

Kegiatan kokurikuler adalah "kegiatan di luar jam pelajaran biasa yang dilakukan di sekolah ataupun di luar sekolah yang bertujuan untuk menunjang pelaksanaan program intrakurikuler agar peserta didik dapat lebih menghayati bahan atau materi yang telah dipelajarinya" (Setiawati, 1993, hal. 17).

3) Kegiatan Ekstrakurikuler

Kegiatan ekstrakurikuler "merupakan kegiatan yang dilakukan di luar jam pelajaran (tatap muka) baik dilaksanakan di sekolah maupun di luar sekolah dengan tujuan untuk mengembangkan bakat serta minat peserta didik dalam upaya pembinaan menuju manusia seutuhnya" (Setiawati, 1993, hal. 22).

Lingkup kegiatan ekstrakurikuler "mencakup kegiatan yang dapat menunjang serta mendukung program intrakurikuler maupun program kokurikuler" (Setiawati, 1993, hal. 22). Kegiatan ekstrakurikuler dapat berupa "kegiatan pramuka, palang merah remaja, seni baca al-Qur'an, Patroli Keamanan Sekolah dan Usaha Kesehatan Sekolah, dan sebagainya" (Setiawati, 1993, hal. 23).

\section{Pengembangan Kurikulum PAI \\ 1. Pengembangan Kurikulum PAI di SMP Nasima Semarang}

Kurikulum adalah seperangkat rencana dan pengaturan mengenai tujuan, isi dan bahan pelajaran serta cara-cara yang digunakan sebagai pedoman penyelenggaraan kegiatan pembelajaran untuk mencapai tujuan pendidikan. Tujuan tersebut meliputi tujuan pendidilan nasional serta kesesuaian dengan kekhasan, kondisi, potensi daerah, satuan pendidikan dan peserta didik, oleh karena itu kurikulum disusun oleh satuan pendidikan untuk memungkinkan penyesuaian program pendidikan dengan kebutuhan dan potensi daerah masing-masing.

Dalam penyusunan kurikulum di SMP Nasima, SMP Nasima mengacu pada standar pendidikan nasional dan panduan yang disusun oleh BNSP yang dikembangkan sesuai dengan kekhasan lembaga pendidikan, wujud dari pengembangan kurikulum di tingkat satuan pendidikan adalah silabus dan RPP.

Struktur kurikulum di SMP Nasima sesuai dengan struktur KTSP pada jenjang pendidikan dasar dan menengah yang tertuang dalam standar isi, meliputi lima kelompok mata pelajaran yaitu: 1) Agama dan akhlak mulia meliputi pendidikan agama Islam (PAI), 2) Kewarganegaraan dan kepribadian meliputi pendidikan kewarganegaraan, 3) Ilmu pengetahuan dan teknologi meliputi bahasa Indonesia, bahasa Inggris, matematika, ilmu pengetahuan alam, ilmu pengetahuan sosial, TIK, 4) Estetika meliputi seni budaya dan 
bahasa Jawa,5) Jasmani, olahraga dan kesehatan meliputi pendidikan jasmani, olahraga dan kesehatan

Dalam pelaksanannya, SMP Nasima Semarang mengacu pada kurikulum yang ditetapkan oleh Departemen Pendidikan Nasional, dimana mata pelajaran Pendidikan Agama Islam dilaksanakan sebanyak dua jam pelajaran tiap minggunya. Melihat hal tersebut terlihat bahwa mata pelajaran Pendidikan Agama Islam sangat minim, apabila dibandingkan dengan tujuan yang ingin dicapai oleh SMP Nasima Semarang sesuai dengan visi dan misi yang disusun.

Untuk menutup kekurangan jam pelajaran Pendidikan Agama Islam tersebut, SMP Nasima Semarang menerapkan beberapa program khusus yang bertujuan untuk menguatkan Pendidikan Agama Islam, yaitu Baca Tulis AlQur'an dan Bahasa Arab yang dilaksanakan secara terstruktur sebanyak dua jam pelajaran setiap minggunya.

Selain itu, untuk menambah dan meningkatkan afeksi peserta didik, SMP Nasima Semarang menerapkan beberapa kegiatan yang disebut kegiatan Keagamaan.

Kegiatan keagamaan adalah kegiatan di luar jam pelajaran biasa yang diadakan di sekolah atau di luar sekolah guna menunjang kegiatan intrakurikuler PAI, untuk selanjutnya penggunaan istilah kokurikuler PAI sama maknanya dengan kegiatan keagamaan di SMP Nasima Semarang yang dalam penggunaan istilah tersebut kadang bergantian, tetapi maksudnya sama.

Tujuan pelaksanaan kegiatan keagamaan SMP Nasima Semarang adalah Agar anak didik memiliki dasar-dasar pengetahuan dan pemahaman agama yang luas dan mendalam, memiliki sikap dan perilaku agama yang kuat dan istiqomah, Melatih anak didik agar terbiasa untuk melaksanakan ibadah (shalat, membaca Al-Qur'an, infaq, sedekah, dan sebagainya) (Panduan kegiatan keagamaan SMP Nasima).

Materi dalam kegiatan keagamaan SMP Nasima menyangkut lima aspek, yaitu: Al-Qur'an/Hadits, bentuknya yaitu BTA, Tadarrus, Hafalan surat-surat pendek. Akidah, bentuknya yaitu pengenalan lingkungan. Akhlak, bentuknya yaitu kegiatan sosial, membiasakan mengawali dan mengakhiri suatu pekerjaan dengan berdo'a. Fiqh/Ibadah, bentuknya pelaksanaan shalat jama'ah dhuhur dan ashar, shalat sunnah (dhuha dan rawatib), pendampingan wudlu. Tarikh, bentuknya PHBI, mengunjungi tempat-tempat bersejarah bagi perkembangan Islam, dan sebagainya.

Pelaksanaan kegiatan keagamaan SMP Nasima terdiri:

- Harian, yaitu kegiatan keagamaan yang dilakukan setiap hari mulai masuk sekolah sampai pulang sekolah. Yang termasuk dalam kegiatan harian yaitu: Tadarrus al-Qur'an dan mujahadah asma'ul husna sebelum pelajaran dimulai, Shalat dhuhur dan ashar secara berjama'ah, 
Membaca do'a-do'a harian. Praktek Ibadah merupakan kegiatan keagamaan SMP nasima yang dilaksanakan secara rutin setiap hari. Praktek ibadah dimaksudkan untuk mengaplikasikan materi yang diperoleh siswa di dalam kegiatan intrakurikuler PAI terutama pada aspek fikih/ ibadah, mengingat materi yang ada pada aspek ibadah/ fikih ini hampir seluruhnya berisi materi yang memerlukan praktek, seperti thaharah, shalat, dan sebagainya. Target nyata pelaksanaan kegiatan ibadah ini antara lain adalah anak didik mampu melaksanakan shalat wajib dan sunnah dengan baik dan benar, mampu melakukan wudlu dengan baik dan benar, dan mampu adzan dan iqomah dengan baik dan benar.

Pelaksanaan kegiatan ibadah di SMP Nasima Semarang merupakan wujud nyata untuk merealisasikan target tersebut. Adapun kegiatan yang tercakup dalam praktek ibadah adalah: Praktek shalat jama'ah dhuhur dan ashar. Shalat Dhuha, Pendampingan wudlu. Dalam pelaksanaan kegiatan praktek ibadah, para siswa SMP Nasima selalu didampingi oleh para guru pendamping yang bertugas mengontrol seluruh aktifitas siswa yang berhubungan dengan kegiatan praktek ibadah. Adapun maksud dari pendampingan kegiatan tersebut karena dalam kenyataan banyak ditemukan siswa yang belum sempurna dalam menjalankan Ibadah, baik dari segi bacaan, gerakan dan tata caranya, misalnya dalam membasuh tangan ketika wudhu banyak yang tidak meratakan air sampai ke siku, shaf-shaf shalat yang tidak rapat, dan sebagainya. Sehingga diharapkan dengan adanya bimbingan dan pengawasan dari dewan guru tersebut kesalahan anak didik dalam melaksanakan Ibadah dapat diminimalisir, selain sebagai bentuk rasa tanggung jawab sebagi seorang pendidik. Berdasarkan hasil pengamatan yang penulis lakukan, dalam pelaksanaan praktek ibadah shalat jama'ah dzuhur yang diawali dengan adzan di masjid SMP Nasima, para peserta didik putra mengambil air wudlu terlebih dulu, kemudian disusul para peserta didik putri dengan pengawasan para guru. Setelah selesai wudhu para siswa langsung menuju ke masjid untuk membentuk shaf-shaf shalat.

- Mingguan, yaitu kegiatan keagamaan yang dilaksanakan seminggu sekali. Yang termasuk dalam kegiatan mingguan yaitu: Bimbingan membaca Al-Qur'an (BTA), Hafalan surat-surat pendek (juz 'amma), Shalat jum'at. Progam kegiatan baca tulis Al-Quran merupakan bagian integral dari bidang Studi PAI pada aspek alQur'an/al-Hadits, mengingat materi pada aspek al-Qur'an /al-Hadits berisi ayat-ayat al-Qur'an dan hadits Rasulullah, sehingga program bimbingan baca tulis al-Qur'an perlu diadakan. Program BTA di 
SMP Nasima bertujuan untuk membantu para anak didik khususnya bagi para anak didik yang belum dapat membaca al-Qur'an, karena kenyataan di lapangan tidak semua anak didik yang datang ke SMP Nasima memiliki kemampuan membaca al-Qur'an dengan baik, bahkan ada yang tidak dapat membaca al-Qur'an sama sekali, sehingga untuk menunjang kegiatan pembelajaran PAI khususnya aspek al-Qur'an /Hadits kegiatan BTA mutlak diperlukan, agar tujuan pendidikan yang ditargetkan dapat terpenuhi. SMP Nasima dalam merekrut tenaga pembimbing program baca tulis al-Qur'an disyaratkan harus hafal al-Qur'an dengan menunjukkan ijazah yang menyatakan bahwa ia benar-benar telah lulus dan telah khatam. Hal tersebut juga dikuatkan oleh wawancara yang penulis lakukan dengan salah seorang pembimbing program baca tulis al-Qur'an yaitu bapak Ulil, serta dari dokumentasi yang penulis peroleh dari bagian keadministrasian. Untuk mempermudah pelaksanaan bimbingan, peserta didik dibedakan menjadi dua kelompk yaitu kelompok yang sudah lancar dalam membaca dan kelompok yang belum lancar, hal tersebut dilakukan agar lebih mudah penanganannya, karena bagi yang kurang lancar dalam membaca akan mendapat bimbingan yang berbeda dengan yang sudah lancar. Berdasarkan pengamatan yang penulis lakukan antara kelompok yang sudah lancar dan yang belum lancar dalam membaca al-Qur'an mendapatkan perlakuan yang berbeda, dimana untuk kelompok yang belum lancar harus mengulang beberapa kali sampai benar-benar lancar, sedangkan untuk kelompok yang sudah lancar mereka diarahkan untuk menghafalkan surat-surat pendek juz 'amma. Untuk memudahkan dalam program bimbingan baca tulis al-Qur'an, para peserta didik juga dibekali dengan pelajaran tajwid, mulai dari hukum bacaan nun mati sampai qharib dalam al-Qur'an.

- Semesteran yaitu kegiatan keagamaan yang dilaksanakan dalam jangka waktu enam bulan. Yang termasuk dalam kegiatan enam bulanan yaitu Pengenalan lingkungan, kegiatan sosial.

- Tahunan, yaitu kegiatan keagamaan yang dilaksanakan dalam jangka waktu satu tahun. Yang termasuk dalam kegiatan tahunan yaitu PHBI seperti peringatan maulid Nabi, Isra' Mi'raj, tahun baru hijriyah, dan sebagainya (Dokumen perencanaan kegiatan keagamaan).

Beban belajar satuan pedidikan SMP Nasima Semarang dilaksanakan dengan menggunakan sistem paket. Sistem paket adalah sistem penyelenggaraan program pedidikan yang peserta didiknya diwajibkan mengikuti seluruh program pembelajaran dan belajar yang sudah ditetapkan untuk setiap kelas sesuai dengan struktur kurikulum tingkat satuan 
pendidikan. Beban belajar setiap mata pelajaran dinyatakan dalam satuan jam pelajaran. Beban belajar dirumuskan dalam bentuk satuan waktu yang dibutuhkan peserta didik untuk mengikuti program pembelajaran melalui penugasan, kegiatan terstruktur dan kegiatan mandiri tidak terstruktur. Semua ini dimaksudkan untuk mencapai standar kompetensi lulusan dengan memperhatikan tingkat perkembangan peserta didik. Kegiatan tatap muka adalah kegiatan pembelajaran yang berupa proses interaksi antara peserta didik dengan pendidik. Beban belajar kegiatan tatap muka per jam pembelajaran berlangsung selama 40 menit. Beban belajar kegiatan tatap muka perminggu di SMP Nasima Semarang adalah 44 jam untuk kelas VII dan VIII dan 48 jam untuk kelas IX.

Kegiatan mandiri tidak terstruktur adalah kegiatan pembelajaran yang berupa pendalaman materi pembelajaran oleh peserta didik yang dirancang oleh pendidik untuk mencapai standar kompetensi. Waktu untuk penugasan terstruktur dan kegiatan mandiri tidak terstruktur bagi peserta didik maksimal $50 \%$ dari jumlah waktu kegiatan tatap muka dari mata pelajaran yang bersangkutan. Penyelesaian program pendidikan dengan menggunakan sistem paket adalah tiga tahun.

Alokasi waktu praktek dua jam kegiatan praktek di sekolah setara dengan satu jam tatap muka, empat jam praktek di luar sekolah setara dengan satu jam tatap muka. Untuk kegiatan praktek di sekolah misalnya pada kegiatan ekplorasi lingkungan yang berlangsung empat jam setara dengan satu jam pelajaran tatap muka, sesuai dengan yang tertulis pada struktur kurikulum SMP Nasima Semarang.

SMP Nasima dalam menetapkan kriteria ketuntasan minimal mengacu pada hasil MGMP guru mata pelajaran yang bersangkutan.

SMP Nasima Semarang menetapkan kriteria keetuntasan minimal (KKM) untuk mata pelajaran PAI adalah 80. Kriteria untuk kegiatan pengembangan diri adalah "baik". Dan kriteria ketuntasan minimal untuk program ciri khusus, yaitu BTA dan Bahasa Arab adalah 74.

Kriteria atau acuan kenaikan kelas SMP Nasima Semarang adalah:

- Kehadiran siswa dalam kegiatan belajar di kelas sekurang-kurangnya adalah $80 \%$ hari belajar efektif dalam satu tahun.

- Menyelesaikan seluruh program pembelajaran pada kelas yang ditempuh

- Tidak ada nilai di bawah KKM khusus mata pelajaran PAI, PKn, dan Bahasa Indonesia.

- Nilai siswa bersangkutan yang belum mencapai kriteria ketuntasan minimal paling banyak 4 (empat) mata pelajaran.

- Tidak ada nilai 50,00 atau kurang untuk setiap aspek penilaian mata pelajaran. 
- Sekurang-kurangnya mendapat nilai baik pada akhir untuk seluruh mata pelajaran kelompok mata pelajaran agama dan akhlak mulia, kelompok mata pelajaran kewarganegaraan dan kepribadian, kelompok mata pelajaran estetika, jasmani, olah raga dan kesehatan.

- Kegiatan pengembangan diri minimal baik

Sedangkan kriteria kelulusan peserta didik di SMP Nasima Semarang adalah:

- Mengikuti kegiatan belajar di kelas IX sekurang-kurangnya adalah $80 \%$ hari belajar efektif.

- Kepribadian sekurang-kurangnya mendapat nilai baik.

- Lulus ujian praktek untuk semua mata ujian.

- Lulus ujian sekolah dengan nilai sekurang-kurangnya 60.

- Lulus ujian nasional dengan nilai sekurang-kurangnya sesuai dengan ketentuan yang ditentukan pemerintah.

Adapun langkah-langkah yang SMP Nasima Semarang ambil terhadap peserta didik yang tidak naik kelas sebagai berikut:

- Peserta didik yang tidak naik kelas harus mengikuti kembali semua mata pelajaran pada tingkat kelas yang sama di tahun pelajaran sebelumnya.

- Mata pelajaran-mata pelajaran yang telah tuntas sebelumnya tetap dijadikan pertimbangan, nilai-nilai yang dicapai minimal sama dengan nilai tahun sebelumnya.

- Peserta didik dibantu semaksimal mungkin agar mampu menyamai atau melampaui KKM setiap mata pelajaran di tahun pelajaran sebelumnya, khusus mata pelajaran yang belum dituntaskan pada tahun sebelumnya.

- Apabila ketidaknaikan kelas terulang kembali untuk untuk peserta didik yang sama, maka sekolah berwenang untuk menentukan langkahlangkah efektif untuk menentukan alternatif model pembelajaran atau lembaga lain yang sesuai untuk peserta didik dengan sepengetahuan orang tua.

\section{Pengembangan KurikulumPAI di SMP Islam Sultan Agung 1 Semarang}

Dalam penyusunan kurikulum di SMP Islam SultanAgung 1 Semarang, SMP Islam Sultan Agung 1 Semarang mengacu pada standar pendidikan nasional dan panduan yang disusun oleh BNSP yang dikembangkan berdasarkan kekhasan lembaga pendidikan, wujud dari pengembangan kurikulum di tingkat satuan pendidikan adalah silabus dan RPP.

Struktur kurikulum di SMP Islam Sultan Agung 1 Semarang sesuai dengan struktur KTSP pada jenjang pendidikan dasar dan menengah yang tertuang dalam standar isi, meliputi lima kelompok mata pelajaran yaitu: 
1) Agama dan akhlak mulia meliputi pendidikan agama Islam (PAI)

2) Kewarganegaraan dan kepribadian meliputi pendidikan kewarganegaraan

3) Ilmu pengetahuan dan teknologi meliputi bahasa Indonesia, bahasa Inggris, matematika, ilmu pengetahuan alam, ilmu pengetahuan sosial, TIK.

4) Estetika meliputi seni budaya dan bahasa Jawa

5) Jasmani, olahraga dan kesehatan meliputi pendidikan jasmani, olahraga dan kesehatan

Dalam pelaksanannya, SMP Islam Sultan Agung 1 Semarang mengacu pada kurikulum yang ditetapkan oleh Departemen Agama, dimana Pendidikan Agama Islam terdiri dari mata pelajaran Al-Qur'an-Hadits, Akidah-Akhlak, Fikih, dan Sejarah Kebuda Islam dilaksanakan sebanyak dua jam pelajaran tiap minggunya.

Untuk menunjang kegiatan intrakurikluler yang telah terjadwal secara terstruktur, SMP Islam Sultan Agung 1 Semarang menerapkan sebuah strategi pendidikan yang disebut dengan Budaya Sekolah Islami atau sering diisebut BUSI.

Budaya Sekolah Islami (BUSI) adalah kegiatan di luar jam pelajaran guna menunjang penguatan internalisasi nilai-nilai Islam bagi peserta didik, antara lain: Shalat dhuhur berjamaah, Sholat Dhuha berjamaah, Etika pergaulan Islam, Etika Berbusana Islam

Shalat jamaah menjadi ciri dari pelaksanaan strategi Budaya Sekolah Islami, selain memiliki nilai pendidikan untuk peserta didik, yaitu membiasakan peserta didik untuk selalu berjamaah dalam melaksankan sholat, juga untuk memupuk rasa dan sikap sosial peserta didi, dimana peserta didik sejak dini dibiasakan untuk membangun jamaah, membangun kebersamaan, melalui kegiatan solat jamaah

Sebelum pelaksanaan sholat jamaah peserta didik diarahkan dan didampingi dalam persiapan sholaat jamaah, mulai dari tata car bersuci/ wudhu, maupun memperesiapkan barisan dalam sholat, yang dimaksudkan untukmemberikan bimbingan dan pengawasan dari dewan guru tersebut kesalahan anak didik dalam melaksanakan Ibadah dapat diminimalisir, selain sebagai bentuk rasa tanggung jawab sebagi seorang pendidik.

Progam kegiatan baca tulis Al-Quran merupakan bagian integral dari bidang Studi al-Qur'an/al-Hadits, mengingat materi pada aspek al-Qur'an -al-Hadits berisi ayat-ayat al-Qur'an dan hadits Rasulullah, sehingga program bimbingan baca tulis al-Qur'an perlu diadakan.

Program BTA di SMP Islam Sultan Agung 1 Semarang bertujuan untuk membantu para anak didik khususnya bagi para anak didik yang belum dapat membaca al-Qur'an, karena kenyataan di lapangan tidak semua anak didik 
yang datang ke SMP Islam Sultan Agung 1 Semarang memiliki kemampuan membaca al-Qur'an dengan baik, bahkan ada yang tidak dapat membaca al-Qur'an sama sekali, sehingga untuk menunjang kegiatan pembelajaran al-Qur'an /Hadits kegiatan BTA mutlak diperlukan, agar tujuan pendidikan yang ditargetkan dapat terpenuhi

Berdasarkan pengamatan yang penulis lakukan antara kelompok yang sudah lancar dan yang belum lancar dalam membaca al-Qur'an mendapatkan perlakuan yang berbeda, dimana untuk kelompok yang belum lancar harus mengulang beberapa kali sampai benar-benar lancar, sedangkan untuk kelompok yang sudah lancar mereka diarahkan untuk menghafalkan suratsurat pendek juz 'amma.

Untuk memudahkan dalam program bimbingan baca tulis al-Qur'an, para peserta didik juga dibekali dengan pelajaran tajwid, mulai dari hukum bacaan nun mati sampai qharib dalam al-Qur'an.

Dalam pelaksanaan pembelajaran, SMP Islam Sultan Agung satu menerapkan kelas terpisah antara peserta didik laki-laki dan peserta didik perempuan, sehingga dengan pemisahan kelas antara peserta didik lakilaki dan perempuan tersebut akan mempermudah dalam melaksanakan pengawasan dan pembimbingan tata pergaulan yang sesuai dengan ajaran Isla

\section{Analisis Pengembangan Kurikulum PAI di SMP Nasima dan SMP Islam Sultan Agung 1 Semarang}

Mencermati model pengembangan kurikulum Pendidikan Agama Islam yang diterapkan di SMP Nasima Semarang dan SMP Islam Sultan Agung Satu Semarang, ada beberapa hal yang dapat dikatakan sebagai langkah inovatif dalam pengembangan pembelajaran, yaitu melalui kegiatan keagamaan dan Budaya Sekolah Islami.

Hal tersebut dapat dilihat dari struktur kurikulum yang digunakan oleh masing-masing lembaga, dimana SMP Nasima Semarang menggunakan kurikulum dari Kemendiknas sedangkan SMP Islam Sultan Agung 1Semarang menggunakan Kurikulum dari Departemen Agama.

Struktur Kurikulum antara Kemendiknas dan Kemenag berdeba, dimana untuk mata pelajaran PAI hanya dialokasikan dua jampelajaran secara terstruktur untuk kurikulum dari Kemendiknas, sedangkan kemenag Pendidikan Agama Islam menjadi sebuah rumpun yang terdiri dari beberapa mata pelajaran (Al-Qur'an Hadits, Akidah Akhlak, Fikih, Sejarah Kebudayaan Islam) dimana masing masing mata pelajaran tersebut dialokasikan dua jam pelajaran dalam satu minggu dalam bentuk pertemuan terstruktur.

Dilihat dari struktur kurikulum yang digunakan, ada perbedaan antara SMP Nasima Semarang dan SMP Islam Sultan Agung 1 Semarang, namun SMP Nasima memiliki langkah strategis untuk menutup kekurangan jumlah 
jam pelajaran terstruktur yang disara kurang, dengan mengadakan program kegiatan keagamaan, dimana dalam kegiatan keagamaan tersebut diisi dengan kegiatan yang mendukung langsung terhadap penguatan dan pemahaman nilai-nilai Islam (PAI)

SMP Islam Sultan Agung 1 Semarang, yang mengacu pada struktur kurikulum kemenag, yang secara jumlah jam pelajaran lebih unggul, tetapi juga menerapkan sebuah strategi tersendiri untuk menambah penguatan dan pemahaman terhadap nilai nilai Islam melalui Budaya Sekolah Islami

Sehingga baik SMP Nasima Semarang ataupun SMP Islam Sultan Agung 1 Semarang masing-masing memiliki strategi tersendiri untuk mewujudkan tujuan pendidikan, tanpa harus terpaku secara kaku terhadap kurikulum yang telah ditetapkan pemerintah, tetapi lembaga-lembaga pendidikan memiliki keleluasaan untuk membuat suatu inovasi dalam pengelolaan pembelajarannya.

\section{Kesimpulan}

Dari uraian sebelumnya tentang model pengembangan kurikulum PAI SMP di kota Semarang, dapat disimpulkan bahwa:

SMP Nasima Semarang dan SMP Islam Sultan Agung 1 Semarang memiliki strategi tersendiri untuk meningkatkan kualitas pembelajaran khususnya untuk mengatasi jumlah jam pelajaran PAI yang dapat dikatakan sangat minim, yaitu dua jam pelajaran setiap minggu, melalui kegiatan keagamaan dan Budaya Sekolah Islami.

langkah yang diambil SMP Nasima Semarang dan SMP Islam Sultan Agung 1 Semarang, merupakan langkah strategis dalam rangka mewujudkan lembaga pendidikan yang berkualitas, sehingga dengan langkah dan kebijakan yang diambil oleh masing masing lembaga tersebut memberikan dampak positif bagi peserta didik, yang akhirnya akan menambah kepercayaan masyarakat terhadap SMP Nasima Semarang dan SMP Islam Sultan Agung 1 Semarang

\section{DAFTAR PUSTAKA}

Departemen Agama RI, Al-Qur'an dan Terjemahnya, Solo, PT. Tiga Serangkai, (tt.)

Abdul Halim, Nipan M., Mendidik Kesalehan Anak, Pustaka Amani, Jakarta, 2001.

Ad-Dimasqy, Imam Faqih Muhaddits Muhyiddin Abi Zakariya Yahya bin Syarof An-Nawawy, Al-Adzkaar An-Nawawiyah.Daru Haya'i AlKitab Al-Arobiyah, Indonesia, (tt.) 
Al-Istanbuly, Mahmud Mahdi, Pendidikan Keluarga Dalam Islam, , Karya Toha Putra, Semarang, (tt.)

Amirul Hadi, H. Haryono, Metodologi Penelitian Pendidikan, Pustaka Setia, Bandung, 1998.

Asmani, Ma'ruf, Jamal, Tuntutan Lengkap Metodologi Praktis Penelitian Pendidikan, Diva Press, Jogyakarta,2011.

As-Samarqandi, Al-Faqih Nashr bin Muhammad bin Ibrahim, Tanbihul Ghafilin, Toha Putra, Semarang, 1993.

Bimo Walgito,Pengantar Psikologi Umum, Yayasan Penerbitan Fakultas Psikologi UGM, Yogyakarta, 1986.

Departemen Agama RI, Al-Qur'an dan Tafsirny, Lembaga Percetakan AlQur'an Departemen Agama, Jakarta, 2009.

Gintings, Abdurrahman,Esensi Praktis Belajar Dan Pembelajaran, Humaniora, Bandung, 2008.

Moleong, Lexy J., Metodologi Penelitian Kualitatif, Remaja Rosdakarya, Bandung, 2001.

Mustaqim, Abdul Wahib, Psikologi Pendidikan, Rineka Cipta, Jakarta, 1991.

Patmonodewo, Soemarti, Pendidikan Anak Prasekolah, Rineka Cipta, Jakarta, 2000.

S. Margono, Metodologi Penelitian Pendidikan, Rineka Cipta, Jakarta, 1997.

Sardiman AM, Interaksi dan Motivasi Belajar-Mengajar, Rajawali, Jakarta, 1990.

Slameto, Belajar dan Faktor-faktor yang mempengaruhinya, Rineka Cipta, Jakarta, 2003.

Sugiyono,Metode Penelitian Kuantitatif Kualitatif dan $R \& D$, Alfabeta, Bandung, (tt.)

Sumadi Suryabarata, Psikologi Pendidikan, Raja Grafindo Persada, Jakarta, 1993. 